\title{
Understanding Sitting Culture of Balinese Traditional Society
}

\author{
Sangayu Ketut Laksemi Nilotama \\ Trisakti University, Art and Design Faculty, Indonesia \\ sangayu@trisakti.ac.id
}

\begin{abstract}
The position and placement of sitting down for traditional activities for Balinese society is being followed. Balinese people possess various names for sitting positions for men and women, that must be recognized and understand by members of the community. It is mentioned that to sit on the floor if conducting various sacred or profane activities, and discussion with priests/members of royalty. The result of descriptive qualitative analysis showed, the position and sitting posture matters towards one's distance and angle, and determined through caste hierarchy. The shape of traditional Balinese house really takes into account the sitting concept, which is the distance between humans in relations to the space organization in conducting activities. The obedience of this sitting ethics has impacts for the experience, towards one's moral values, not only about appreciating caste hierarchy, but also the commitment to live harmoniously amongst members of society.
\end{abstract}

Keywords : Balinese traditional society, sitting culture, caste hierarchy

\section{THE BALINESE TRADITIONAL LIFES}

Bali is one of the many islands in Indonesia that bear many uniqueness in traditions. The Balinesse traditional lifes can not be seperated from tradition, ritual and religious custom which are inherited from the past and managed within the manners in the traditional village. Manners are social ethics that regulate norms in the lives of their people. Besides that there are customs and habits that are carried out by the group then develop and influence the order of behavior of Balinese Hindu people especially for the village community. The behavior will be discussed about the tradition of sitting habits for the Balinese people. Sitting on the floor or sitting without a chair is a common practice for Balinese people, especially for activities related to rituals, customs and traditions. The sitting position and placement on the floor is usually done on a number of situations such as: when they pray, when they apply for a bride, when making offerings, when preparing / dispensing food, eat together (megibung), sitting relaxed with his family, when they came to a priest (pedanda) to consult and et cetera. In activities related to ritual and religious Balinese people always consult with religious leaders. They consult to get the best day (subhadiwase) to hold a ceremony, such as: wedding ceremony, death ceremony, birth ceremony and building a house.

Usually people come to visit the house of the religious leader called priest/Pedanda, the activity of visiting priest called tangkil/nangkil. In one day a pedande can accept several family groups or community groups. The nangkil group uses traditional dress and carries several items in the form of rice, sugar, coffee, flowers and sometimes in offerings supplemented with money. People who come for the purpose of nangkil to the Griya or to

Puri usually use traditional clothing such as kebaya cloth and clothes (for women), and saput cloth (for men). The nangkil activities of community groups are also carried out to government leaders for example to the king and the nobility. A visit to Puri is usually related to profane activities, such as: government problems, reporting on village developments and problems, inviting in an event. Usually the homeowner accepts their arrival in an open space in a building generally known as a terrace. They were welcome to sit on the terrace of the building and wait until the pedanda was present to meet them.

Based on the author's observation, there is an interesting situation especially for Balinese people who live in the traditional village (desa pakraman), that seeing guests who come does not sit in chairs but sit on the floor. This situation is very different from other habits that are carried out in the city community, if it is normal to visit the homeowner in a room and invite to sit on a chair. This simple issue is the author's interest in discussing it, so the focus of the discussion in this study is the traditional relationship of sitting on the floor in relation to the shape of the building. The uniqueness of traditional Balinese buildings consists of various forms, functions and users of the building. The buildings are also determined based on the provisions of the location and direction, called the mandala.

\section{LITERATURE REVIEW}

The difficulty in discussing the topic of this writing is that there is no special text on sitting culture or the way the Balinese sit in the study, it is only limited situationally described as a small part of a sentence. Situational situations are sitting cross-legged and crosslegged during prayer, while dancing, dalang presents wayang stories and several other situations. So that to look for literature specifically discussing sit culture is obtained from observation, documentation and interview process. Photo documentation was obtained from several books that showed evidence that the sitting culture had taken place since the time of the kingdom in Bali. Even this situation can still be seen and implemented until the time of writing. Other supporting literaturs were obtained from traditional Balinese 
architecture books, Balinese cultural books, history books of Balinese kingdoms.
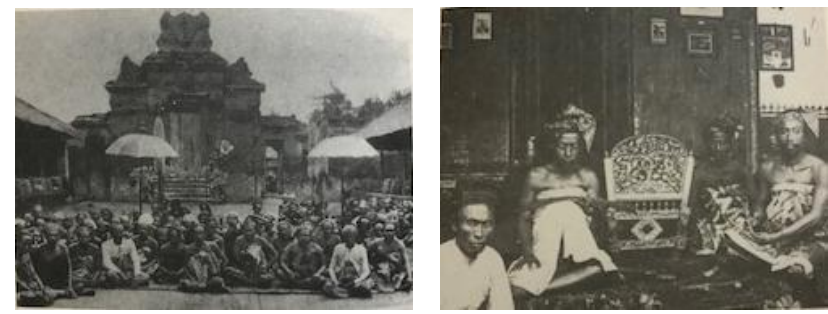

Figure 1. The Radja of Gianjar and his punggawa sitting on the floor (bersila) in the front courtyard of the palace, 1920 Source : Bali Chronicles, page 134 and 173

\section{Aspects of Cultural Value, Aspect of Trust, and Aspects of social status.}

Based on Atmaja (in Dharmayuda, 1995), in the framework of forming a national culture rooted in regional culture must be seen from the horizontal and vertical interaction processes. These interaction processes means that the regional culture can be lifted into the peaks of regional culture if the interaction in the midst of society can be accepted, especially in terms of aesthetics. While verifiers there are benchmarks that indicate they can be accepted ideologically and politically at the national level, that is not contrary to Pancasila. Aspects of Cultural Values, aspects of trust and aspects of social status in the indigenous people of Bali

\section{Aspects of Cultural Value}

In the view of life of Balinese people, the principle of harmony is the principle that prioritizes living in harmony between humans and the creator, human beings with humans, and humans with the environment (between macrocosmos/bhuwana agung and microcosmos/bhuwana alit), is a principle that is considered valuable in life. In the concept of harmony in addition to the harmony of human life but more to the desire to be in harmony between humans and the universe in order to maintain a balance between negative forces (bhuta) and positive forces (deitys) in the universe.

\section{Aspect of Trust}

The customary village community (desa pakraman) in Bali is a society that is very obedient to show religious characteristics such as elements of trust, ritual activities and traditional abstinence activities have important place and meaning in various aspects of their lives. The form of trust that is associated with Balinese housing, namely that the house is believed to be a living element that is reflected in the attitude and behavior of people towards the element. These attitudes and behaviors are manifested in ritual actions in the form of ceremonial activities linked to housing. The ceremonies are divided into several rituals, such as: starting when opening land that will be erected by the building, selection of wood materials to build houses, and the process of building a house. The ceremony continued when the house was finished and ready to be occupied. These religious ritual activities will be repeated in one particular cycle according to the Balinese calendar system (the calculation of 'sasih' $=355$ days) or the Javanese calendar system (the calculation of ' $u k u^{\prime}=210$ days). A number of abstinence customs that are violated will get sanctions that are spiritual, so that the violations that occur are perceived to bring negative consequences, such as illness, disaster, family does not get along well and et cetera.

These restrictions include the pattern of laying yards and structures which are prohibited, for example: the location of 'Meten' may not be paired with 'Paon', not to occupy a building that has been partially cut (nagasena); The yard of the house should not be flanked by the yard of the house from one other family group (karang apitan), the yard of the house should not be given water from other people's houses (karang kebo amuk) and some other restrictions.

\section{Aspects of social status.}

Stratification of Balinese customs based on the nationality system. This nationality system is manifested in various ways that have been passed down through generations, such as in the use of language, the symbol system and et cetera. In the use of language is very concerned with norms such as: the use of subtle/polite language to the markers or to the higher class and to parents. In the symbol system in housing, it is seen in the symbol of nationality by giving the identity of the housing pattern. Housing in the Balinese community based on the status of homeowners is divided into four patterns, namely: Griya, Puri, Jero and Umah.

1. Griya is the designation of a place of residence of the Brahma's caste (wangsa), a house for pedanda, the housing pattern reflects its status as a religious leader, as a provider of 'ala ayuning dewase' as a place for giving advice, virtue/wisdom, and a place for people to ask for holy water (tirta). Griya's characteristic with the bale paweda, building where pedanda performs worship. Griya functions more focused on religious ritual activities.

2. Puri is a place to live from the family of the Ksatria's caste, the royal family. The shape of the building is usually three-tier floors, according to the status of the king as the holder of the customary government. Puri has the typical characteristics of building names such as: ancak saki, semanggen, rangki, saren, bale tegeh, kulkul, pejenengan and others according to their functions. The function of Puri and Jero as a place to protect the community.

3. Jero, is a place to live from the house of the Ksatria's caste but does not hold the government directly. The layout pattern of the building is simpler than Puri.

4. Umah, is the residence of the Wesia's caste, housing locations occupy the North, South, East and West sides of the village road. The orientation center to the grand intersection is the center of the village or Bale Banjar. The function of Umah to the activities of 
residents as farmers (fields, fields, plantations), fishermen (swamps, sea).

\section{Shape of the Buildings/Bale}

There are several characteristics of Balinese buildings. First, the building is open on $1-4$ sides, an open area is used as an interaction area between families, performs ritual activities and as an area to receive guests, while a closed area that forms a space is used as a bedroom or storage room. Second, there is an understanding of space or an open area called Natah. Every traditional Balinese house or building has Natah, namely natah Pura, natah prayer place (sanggah/merajan), natah bale, natah dapur (paon). The concept of natah is a manifestation of the differences in 3 world, namely the deitys world, the human world, and the natural world. Natah is a symbol of the three realms. Natah in traditional Balinese architecture is an open space which is a center of orientation of the surrounding buildings and has a function as profane and sacred activity.
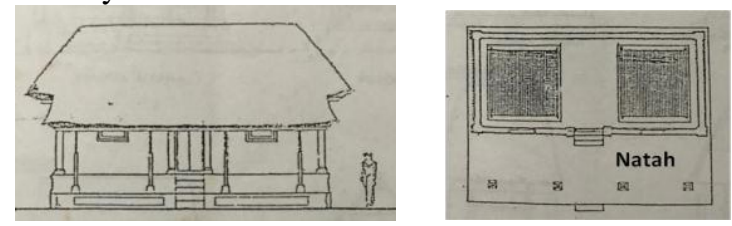

Figure 2. Type of building/ Bale with seven poles (Sakutus) has Natah Bale

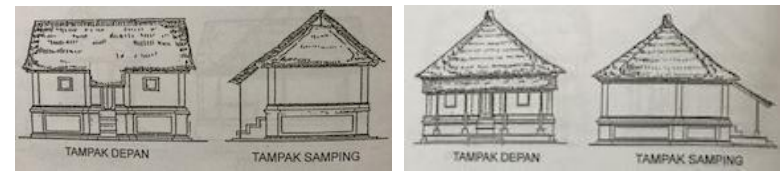

Figure 3. Front side and side side of Bale Meten Sakutus and Bale Meten Gunungrata

This paper will only discuss the interaction of sitting position and placement of a Pedanda and his people when receiving his people at Griya. The shape of the Griya building consists of several forms that are in accordance with the function and inhabitants, in this study the form of the building to be discussed is only the building where the pedanda is located. A pedanda occupies a building called Lodji and Gedong. Lodji is usually occupied by male pedanda (pedanda lanang), while Gedong is occupied by female pedanda (pedanda istri). The shape of the building consists of two space : closed and open space. The closed space serves as a sleep resting activity, reading. Whereas open space serves as a place to receive people, make offerings, read and other activities.

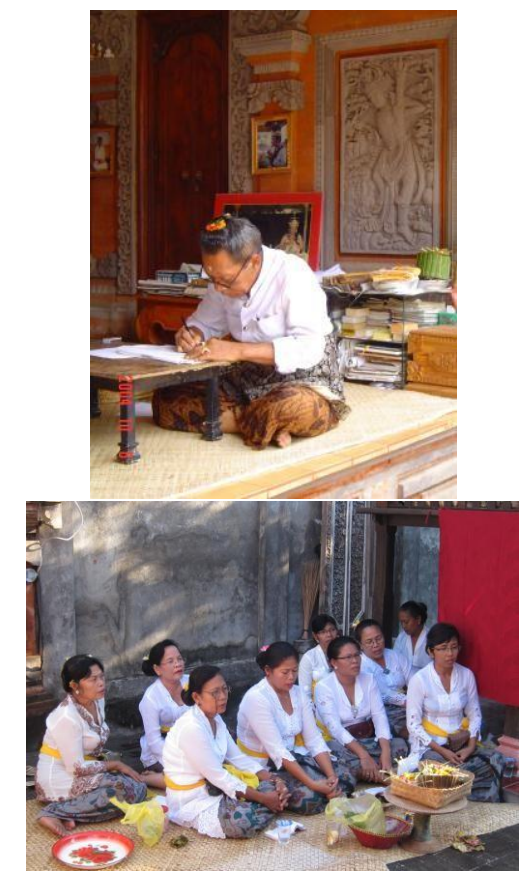

Figure 4. Sitting position for man (bersila) and women (metimpuh)

\section{PROBLEM STATEMENTS}

The westernization process has an important role in social changes in Bali. The effects caused by advances in trade, the fields of communication, industrialization, and urbanization have led to a change especially those that are closely related to the social system. Progress in the field of communication such as the telephone, smartphone can make the nangkil tradition will be eroded from the lives of Balinese people. This research question leads to how the Hindu Balinese society is able to maintain/preserve the meaning behind the cultural tradition of sitting amid the rapid communication of globalization and modernization technology? The research purposes of phenomenological research is to understand how to exist, understand the meaning of the past. The meaning of understanding is different from the meaning of knowing. Understanding implies the ability to feel something that others experience.

\section{METHODOLOGY}

This descriptive phenomenology research uses a qualitative method aimed at finding the essence of the experience of a group of people. In Husserl's phenomenological research there are 3 steps that must be taken, namely : 1. Phenomenological reduction (phenomenological transcendental reduction), 2. Eidetic reduction, and 3. Eidetic variation (imaginative variation). Hermeneutics comes from the Greek, word hemeneuein which means translating or acting as an interpreter. Hermeneutic is also defined as an activity or busyness to reveal the meaning of a text, while the text can be interpreted in a network of meanings or structures of symbols in the form of writing or other forms. Understanding is a process of capturing the intent or meaning of the words spoken by the speaker. The object of understanding is language, but language cannot be separated from the mind of the speaker. At the phenomenological reduction stage is a presentation of 
the natural conditions/situations of human attitudes, how the human process experiences and feels without researchers questioning the reality of these processes. Researchers are not allowed to giving opinions, theories, thoughts and not giving judgments (urteilsenhaltung or delaying judgment - epoche) about their daily lives (Sumartono, 2017). Balinese people, especially Hindus, have many traditions which until now they have lived, one of which is the tradition of Tangkil Nangkil. This tradition is in the form of a visit activity carried out by a person or group to the house of a pedanda or to the Puri where a king/noble descent lives. The visit was generally for consultation on various matters relating to religious ceremonies and customary activities. During this visit they dressed in traditional clothes such as wearing clothes for women, wearing clothes for men, they came to bring in their hands (atos) in a container (bokor/besek) containing rice, sugar and coffee. In this consultation process they were received in a building where the pedanda lived. There is another form of visit called a visit, the nature of this visit is more to the situation conditions that are being experienced by the families visited. Visiting means to visit the family who is experiencing grief, being sick, giving birth, helping voluntarily carry out a ceremony/upakara (ngayah) and et cetera. At the time of visiting them they bring more variety, such as yellow white cloth, flowers, incense, food and money.

At the eidetic reduction stage, it is marked by efforts to find universal essences that are generally accepted based on intuition obtained repeatedly, the essence is not obtained suddenly but based on a period of time which will then be comprehensively summarized. In the next stage, eidetic variations, that each phenomenon empirically has many possibilities (horizon of posibilities), means that the culture of sitting on the floor of Balinese people is viewed from a different perspective, for example : because there are no seats to sit because of practicality, because of differences in castes (wangsa), because traditional Balinese building forms have such forms and et cetera. Looking from another horizon is not to shift the initial view but to see it better in a broader and more correct proportion. The horizon of the past is not to be abandoned, while the future horizon is made possible for a development, a heritage from the past. This paper observe at sitting culture from the point of view of traditional building forms associated with nangkil culture which is still carried out by Balinese people, especially for people who live in traditional villages (desa pakraman).

\section{RESULTS OF ANALYSIS}

The people basically want to consult, they ask for input on things they do not understand the point is they are in a emptiness of opinion, looking for a way out of the problems they are facing. In their belief that every day has the character of good and bad, so that the people need an opinion from the pedanda to be able to help and give advice. They asked for a good day to build a house, propose, marriage, birth, and a good day for the ngaben ceremony (cremation). Pedanda will open sacred lontars, see the Balinese calendar, and several other books/scripture. The purpose of this meeting is to harmonize the universe between the bhuwana alit (microcosm) and bhuwana agung (macrocosm), as a principle that is considered very valuable in life. Living in harmony in Balinese society will bring peace of mind, also the achievement of the ideals of maintaining a balance between negative power (butha) and positive power (gods) in this universe.

Based on the form of the house, it appears that the shape of the Brahmin house has terraces with one to two terraces. The function of this terrace is as a pedestal to carry out its daily tasks of making offerings, accepting the people who want to consult about good days.
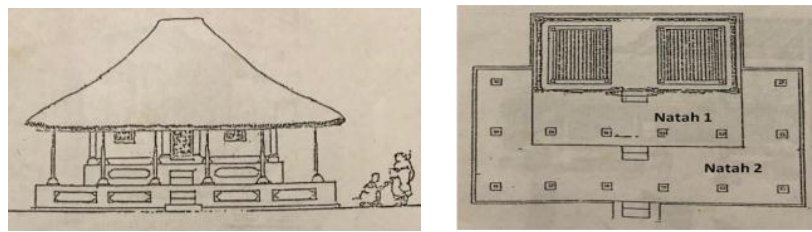

Figure 5. Front View and Top View Bale has two levels/ natah
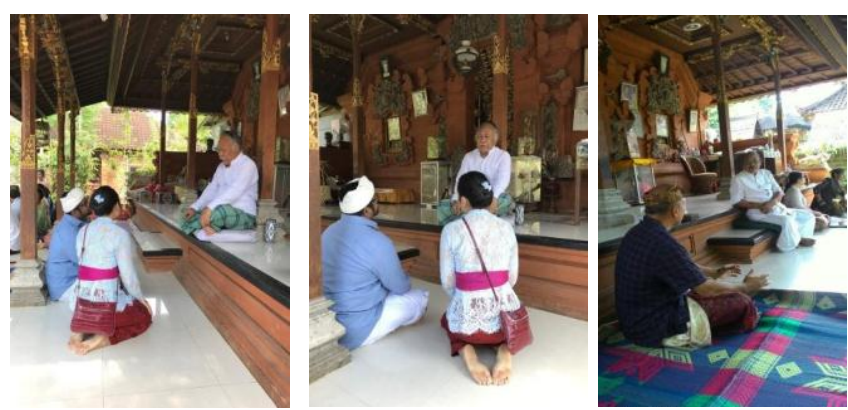

Figure 6. Building View : the position, placement and orientation of sitting with two Natah

To know the basic concepts of traditional Balinese architecture in the design process, we must first know the basics of Hindu religious beliefs. Philosophy of life is associated with the realist view of the purpose of life and community life in an attempt to achieve spiritual peace and physical well-being known as: "Moksartham Jagadhitaya ca iti Dharma", which means that the purpose of this religion is to achieve well-being of the universe and achieve moksa (immortality hereafter). Based on the philosophy of life then becomes the basis of the implementation of religious ceremonies and customs, daily life, and the process of designing a building or other works. The basic concept of the building regulations is part of Balinese life: Tri Loka and Tri Angga. The Balinese have a concept about the world, that the universe (Bhuwana) has three parts, called Tri Loka, namely: Upper World (Swah Loka), Center World (Bhuah Loka), and Lower World (Bhur Loka).

Each world has unique characteristics, namely: Swah Loka is the Utama - the place of the gods, is located on top, Bhuah Loka is the Madya - where people live, and Bhur Loka is Nista - where other creatures. From this was born the concept of Tri Angga natural circumstances, namely: Utama/the MainMadya/Associate-Nista/simple, which is the basic 
values of decency prevailing in Bali custom vertical (horizontal - linear in the call Tri Mandala) and this concept is reflected in the hierarchy and the value of homes in rural areas. Tri Loka elements: Swah Loka, Loka Bwah, and Bhur Loka. While Tri Angga elements: Utama, Madya, and Nista.

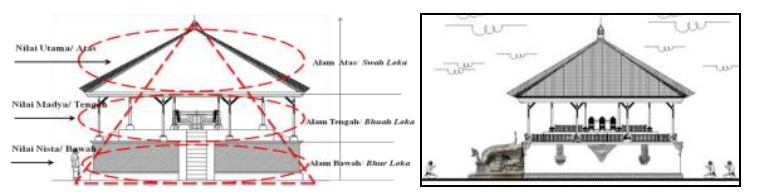

Figure 7 . The basic concept of the building regulations is part of Balinese life: Tri Loka and Tri Angga

Natah has the meaning of emptiness, harmony between the macrocosm and the microcosm, and the meeting of the upper nature and nature/lower world (purusa and pradana). Universally natah has the function to function as a place of activity, social reflection of society in a spiritual, socio-economic, socio-cultural manner, so that it can be said that the function of natah is multifunctional. Natah is not the same as the page/yard in the communal open space. It is in terms of traditional Balinese architecture, as an empty space surrounded by a cluster of buildings. Each cluster of buildings has natah. Based on the direction orientation, each building refers to the sangamandala (9 patterns) as the sacred direction of North and East. The sacred direction is manifested in the arrangement of the inner layout such as the direction of the bed, the kitchen, the place of worship. For large dimensions/sizes small natah is geometric in shape, as open space to four sides and there are dividers on two to four sides.

The natah function is distinguished by the two characteristics of activity, which are sacred and profane. Sacred is related to religious ceremonies, profane deals with daily activities and is not directly related to religious ceremonies, such as drying the produce of the fields, receiving guests, chatting with family. Then it can be said natah as a facility that can accommodate all activities that exist in a family together with the community.

The position of the activity can be done in the condition of standing and sitting, standing conditions when dynamic activities such as dancing, cleaning the house, daily life. While the sitting position is carried out making offerings (mejejahitan), receiving traditional guests/ consulting with pedanda, reading ejection (lontar), and relaxing with family.

The sitting position and placement are also formed from the shape of the natah bale of the building, there are 3 (three) forms of natah bale, there is a bale that has 1 (one) natah, has 2 (two) natah, a bale which does not have natah. In the bale which has one natah, the sitting position of the guests/people and pedanda are parallel, usually the pedanda position sits facing out of the building and the people is seated facing the building. In the bale which has two natah, the sitting placement of the guest/people is very different. The pedanda sitting placement (melinggih) is on the top floor and the bersila position (see Figure 4. natah 1) and the sitting placement of the guest is downstairs and metimpuh position (for women) and bersila position (for man) (see Figure 4. natah 2), and the orientation towards the pedanda sits facing out of the building and the people sit facing into the building. The direction facing out and into the building, has the nature that the direction of the pedanda gives all views, advice and information to the people, while the direction towards the people into the meaning of seeking advice and will receive advice and assistance from the pedanda.

Therefore the meaning of natah and the meaning of the position, placement and orientation of the seated direction are very closely related to creating harmony, peace, inner peace, the creation of a harmonious relationship between natah as the connecting element between the bhuwana alit and the bhuwana agung.

\section{CONCLUSION}

The people basically want to consult, they ask for input on things they do not understand the point is they are in a emptiness of opinion, looking for a way out of the problems they are facing. Seated and cross-legged sitting position shows the ethics of politeness and humility of a person in the process of discussion, equal position between humans. A priest/ pedanda also in a cross-legged sitting position indicates that a good sitting attitude is the sitting position of the padmasana, that is the right foot is placed on the left foot and the left foot is placed on the right foot (such as the Yoga Asana position). Sitting metimpuh folding and occupying two legs, has the meaning of uniting yourself with the soil. Bringing together the two elements of the purusa and pradana meeting of the heavens and the land. Purusa is a psychic element and pradana is a material element. The meeting of these two elements produces the seeds of life, gives prosperity, gives happiness. Natah as empty space has the meaning of emptiness, deeper meaning is in emptiness lies essential truth, emptiness can be understood as meaning about content. In emptiness it is actually not empty, but empty it actually contains or emptiness is loaded with meaning.

\section{ACKNOWLEDGEMENT}

This research has not been completed because it is more focused on how to understand how to sit on the floor in Balinese society which has become a tradition from the perspective of empty space architecture (natah). This research can be developed from a different perspective, such as social conditions, activities that are sacred and profane and et cetera.

\section{REFERENCES}

"Desa Adat, Kesatuan Masyarakat Hukum Adat di Propinsi Bali." I Made Suarthawa Dharmayuda. Upada Sastra. Bali.2001.

"Dharmaning Hasta Kosali Arsitektur Tradisional Bali."Ida Bagus Gede Wiana. Dharma Pura.Denpasar Bali.2011.

"House Form and Culture." Amos Rapoport. PrenticeHall.,INC.,Englewood Cliffs. New

York.1969. 
"Human Behavior: Psychology and Religion." Robert T. Lewis. The Roland Press Company.

New York.1974.

"Jurnal Permukiman Natah", Denpasar. Volume 1, no.1 Februari 2003.

"Kebudayaan Bali, Pra Hindu, Masa Hindu dan Pasca Hindu."I Made Suasthawa Dharmayuda.CV. Kayu Manis, Denpasar.1995

"Metodologi Penelitian Kualitatif." Sumartono. Pusat Studi Reka Rancang Visual dan Lingkungan. Fakultas Seni Rupa dan Desain. Universitas Trisakti.2017. 